$\log \left[\mathrm{Cl}^{-}\right]=1.62 \log \left[\mathrm{OH}^{-}\right]+1.84$

このときの $\mathrm{pH}$ は12.68である。

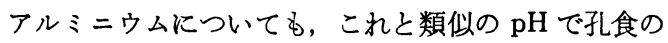

発生がなくなるようであるが目下検討中である。

\section{4. 結 論}

アルミニウムの $0.5 \mathrm{~N} \mathrm{NaCl}$ 溶液に打ける孔食電位と保 護電位をポテンシオスタットを使用して測定した。

得られた結果はつぎのとおりである。

(1) $\mathrm{pH} 4$ の0. $5 \mathrm{~N} \mathrm{NaCl}$ 中のアルミニウムの孔食電位 は2つあって, 第 1 の食電位は-1.15V, 第 2 の孔食 電位はー0.73Vで，保護電位はー1.20Vである。

(2) $\mathrm{pH} 6$ の0. $5 \mathrm{~N} \mathrm{NaCl}$ 中のアルミニウムの孔食電位

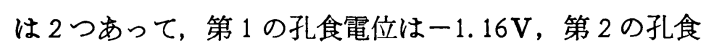
電位はー0.72Vで，保護電位はー1.20Vである。

(3) $\mathrm{pH} 8$ の $0.5 \mathrm{~N} \mathrm{NaCl}$ 中のアルミニウムの孔食電位 は 2 つあって, 第 1 の孔食電位は $-1.16 \mathrm{~V}$, 第 2 の孔食 電位はー0.70Vで, 保護電位はー1.16Vである。
(4) $\mathrm{pH} 10$ 0. $5 \mathrm{~N} \mathrm{NaCl}$ 中のアルミニウムの孔食電位 はー0.7V，保護電位はー1.16Vである。

(5) $\mathrm{pH} 12$ 120.5 N NaCl 中のアルミニウムの孔食電位 は一-0.52V，保護電位はー1.89Vである。

終わりに実験を担当してくださった小沼博君に厚く感 謝いたします。

(1972-10-19 受理)

\section{文献}

1）加藤正義, “アルミニウムの腐食, 溶解機構とその 電池への応用”, (学位論文)

2）杉本克久, 沢田可信, 森岡進, 金属学会誌, 30, 971 (1966)

3) M. Pourbaix, "Atlas of Electrochemical Equilibria in Aqueous Solutions" (1966), Pergamon Press

4) E. Raijola, A. Davidson, J. Am. Chem. Soc., 78, 556 (1956)

5) M. Garreau, Métaux Corrosion, Industrie, 541, 291 (1970)

6) H. P. Leckie, H. H. Uhlig, J. Electrochem. Soc., 113,1262 (1966)

\title{
高圧-低速条件下における高合金鋼のスベリ 摩耗特性について
}

\author{
竹内栄 一*
Sliding Wear Properties of High Alloy Steels under Conditions of High Pressure and Low Velocity

Eiichi TAKEUCHI

In this paper, the dry-sliding wear properties of SKD 11 and SKH 9 under conditions of high pressure and low velocity are discussed ; these samples are industrially utilized as mold forming materials in cold forming. Particularly, these alloy steels were used as stators, while sulfurized or phosphated low carbon steels were used as rotors cooperating with the side stators.

The results showed that in the range of contact pressure of $500 \sim 1500 \mathrm{~kg} / \mathrm{cm}^{2}$ and sliding velocity of $0.05 \sim 1.00 \mathrm{~m} / \mathrm{sec}$., the surface layers of phosphated rotors broke away at their earlier stage of wear, which resulted in metal transfer due to adhesion.

Whereas, little adhesion was observed on the sulfurized rotors. A part of porous sulfurized layers spalled away as wear powder, which adhered to the sliding surface of counter experimental piece. Then, the wear loss between the two sulfurized layers grew remarkably less.

It was also observed that when the wear ratio varied in the velocity-wear property curve, the wearing mechanisms were nearly identical with those mentioned above.

It was further observed that the wear of underhardened material was slightly larger than that of ordinarily quenched and tempered one, because the hardness of the former was much lower than that of the latter.

* 東京都立工業技術センター（東京都北区西ヶ丘 3-13-10） The Tokyo Metropolitan Industrial Technology Center 


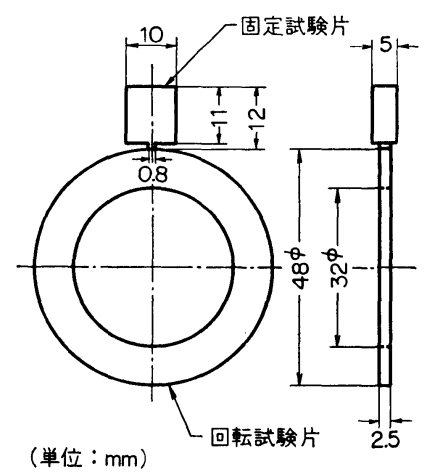

図 1 実験に用いた摩耗試験片

\section{1. 緒言}

最近に打ける金属加工の技術的な進歩, 発展は著しく，ことに冷間成形については これがきわめて生産性の高いことから，その応用範囲の 漸次払大される傾向がみられる。したがって被加工材の 加工性に関してはすでに多くの研究が報告されてい る1)。しかし金型材料の合理的な選択とこれにともなら 熱処理，ならびに高圧低速条件下に和ける摩耗特性を解 明した研究はきわめて少ない2。

本研究は比較的多量生産に適する金型材料としてはん 用されている高炭素高クロムダイス鋼あるいはモリブデ ン系高速度鋼について通常の条件で焼入レ, 焼モドシ処 理したもの，执よび耐摩耗性を可及的そこなわない範囲 で，しかも耐衝撃珄を向上させる目的から Under har dening を施したものを，それぞれ潤滑皮膜処理した低 炭素系構造用鋼と組み合わせて高圧一低速条件のもとで 乾燥ースベリ摩耗を行ない, 上述の各金型材料ならびに その熱処理が摩耗特性に拉よぼす影響を吟味したもので ある。

\section{2. 実験に用いた試験片および方法}
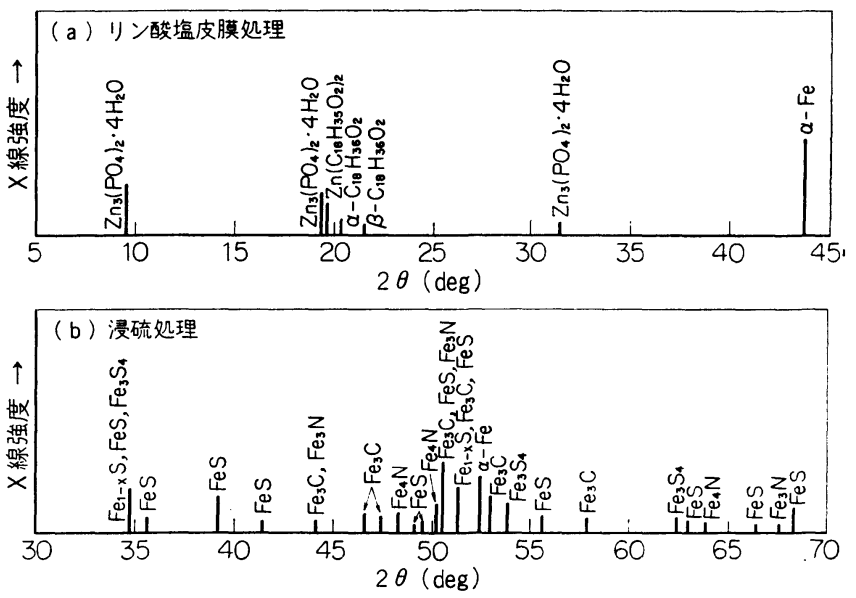

(X線回折条件; ( (a)Target, Cu. Filter, Ni. Voltage, 30kVp, Current, $10 \mathrm{~mA}$ (b), Co. ", Fe. ", ,30kV, "

図 2 表面処理を施した S $15 \mathrm{C}$ (回転試験片) の表面層に打ける反応 生成物の解析

\section{2-1 実験に用いた試験片}

摩耗実験に打いて，金型に相当する 固定試験片には SKD11 および SKH 9 を用い，これを図 1 に示すごとき 寸法, 形状に機械加工したのち, 表 1 の熱処理条件にした がって焼入レ，焼モドシあるいは Under hardeningを 施した。またこれと組み合わせる回転試験片には冷間成 形に適する低炭素系構造用鋼のらちからS15Cならびに $\mathrm{SCM} 21$ の 2 種類を選び， $900^{\circ} \mathrm{C}$ で焼ナマシを行なった のち図 1 に示す円板状に仕上げ，さらにリン酸塩皮膜処 理または $570^{\circ} \mathrm{C} て ゙ 2 \mathrm{~h}$ 浸硫処理 $(\mathrm{NaCN} 25 \%, \mathrm{NaCNO}$ $26 \%, \mathrm{NaCl} 21 \%, \mathrm{Na}_{2} \mathrm{CO}_{3} 28 \%$ の混合塩浴に $\mathrm{Na}_{2} \mathrm{~S}_{2} \mathrm{O}_{3}$ を $5 \%$ 添加，融点は $480^{\circ} \mathrm{C}$ ）を施した。

な敃摩耗実験前に打ける固定試験片のスベリ面の表面 アラサは $R \max 1.0 \mu$, 回転試験片のそれは $\operatorname{Rmax} 3.0 \mu$ である。

つぎにリン酸塩皮膜ならびに浸硫処理した回転試験片 のスベリ面付近に拈ける反応生成物をX線回折により同 定し，その結果の一例を図2に示した。これによると，

表 1 固定試験片の熱処理条件とスベリ面付近のカタサ

\begin{tabular}{|c|c|c|c|c|c|c|c|c|}
\hline \multicolumn{2}{|c|}{ 固定試験片 } & \multicolumn{2}{|c|}{ 焼 入 } & \multirow{2}{*}{$\frac{\text { 焼 }}{\text { 温度 }\left({ }^{\circ} \mathrm{C}\right)}$} & モ & シ & \multirow{2}{*}{$\begin{array}{c}\text { スペy面付近 } \\
\text { の平均力 タ } \\
\left(\mathrm{H}_{\mathrm{R}} \mathrm{C}\right)\end{array}$} & \multirow{2}{*}{ 摘 } \\
\hline 鋼 種 & 記号 & 温度 $\left({ }^{\circ} \mathrm{C}\right)$ & 冷却方法 & & 時間 $(h)$ & 回 数 & & \\
\hline \multirow{2}{*}{ SKD11 } & A & 980 & 油 冷 & 180 & 1 & 1 & 63 & 普通焼入レ，焼モドシ \\
\hline & B & 880 & " & 180 & 1 & 1 & 53 & Under Hardening \\
\hline \multirow{2}{*}{ SKH 9} & C & 1200 & 油 冷 & 560 & 0.5 & 3 & 64 & 普通焼入レ, 烍モドシ \\
\hline & $\mathrm{D}$ & 1050 & $"$ & 250 & 2 & 1 & 57 & Under Hardening \\
\hline
\end{tabular}

注 1. 予熱条件; $\mathrm{SKC} 11,600 \sim 700^{\circ} \mathrm{C}$

SKH $9,600^{\circ} \mathrm{C} \sim 700^{\circ} \mathrm{C}$ 扰よび $900 \sim 950^{\circ} \mathrm{C}$

注 2. 予熱および焼入温度に加熱中はふ儿用気ガスとして乾燥窒素を使用 
リン酸塩皮膜処理したS $15 \mathrm{C}$ の場合，表面から数 $\mu$ の表 面層には $\mathrm{Zn}_{3}\left(\mathrm{PO}_{4}\right)_{2} \cdot 4 \mathrm{H}_{2} \mathrm{O}, \mathrm{Zn}\left(\mathrm{C}_{18} \mathrm{H}_{35} \mathrm{O}_{2}\right)_{2}, \alpha \cdot \mathrm{C}_{18} \mathrm{H}_{36} \mathrm{O}_{2}$, $\beta \cdot \mathrm{C}_{18} \mathrm{H}_{36} \mathrm{O}_{2}$ などが検出され，また浸硫処理した鋼では 表面から $25 \mu$ 前後の表面層に $\mathrm{FeS}, \mathrm{Fe}_{1-\mathrm{xS}}, \mathrm{Fe}_{3} \mathrm{~S}_{4}$ など の硫化物, $\mathrm{Fe}_{3} \mathrm{C}, \mathrm{Fe}_{3} \mathrm{~N}, \mathrm{Fe}_{4} \mathrm{~N}$ などの炭, 窒化物が $\alpha-\mathrm{Fe}$ 之共存するいわゆる正常な反応生成物 ${ }^{3)}$ を同定す ることができた。

\section{2-2 実験方法}

摩耗実験は乾燥状態のもとで $100 \%$ スベリ摩耗方式に より行なっだ〉。この場合, 単位面積当たりの接触圧力 を500〜 $1500 \mathrm{~kg} / \mathrm{cm}^{2}$ の高負荷状態とするため固定試験片 のスベリ面を前掲 図 1 に示すごとく $0.8 \mathrm{~mm}$ 幅に仕上 げ，見かけ上の接触面積を $2.0 \mathrm{~mm}^{2}$ とした。

つぎに各試験片の摩耗率は, 定常摩耗状態のもとで単 位スベリ距離 $100 \mathrm{~m}$ における筫位面積当たりの重量減少 量をミクロテンビンによりヒョウ量した結果から求め た。

また摩耗機構については固定ならびに回転試験片のス ベリ面を光学顕微鏡あるいはX線マイクロアナライザー （以下X. M. A と略記する）による 2 次電子線像, 特性 $\mathrm{X}$ 線像などで観察するとともに，摩耗粉末をX線回折に よって吟味した結果から総合的に判断した。

\section{3.リン酸塩皮膜処理した鋼と組み合わせた 高合金鋼の摩耗特性}

前掲表 1 に示寸普通焼入レ, 焼モドシ処理を施した SKD11 の固定試験片と焼ナマシ後リン酸塩皮膜処理し たS 15Cの回転試騟片を組み合わせて乾燥一スベリ摩耗 実験を行なった。すなわち摩耗条件には接触圧力 500 お よび $1000 \mathrm{~kg} / \mathrm{cm}^{2}$ を選び，スベリ速度を $0.05 \sim 1.00 \mathrm{~m} / \mathrm{s}$ の範讲に変化させて各圧力のもとに护る定常摩耗域で の速度一摩耗特性曲線を求めた。

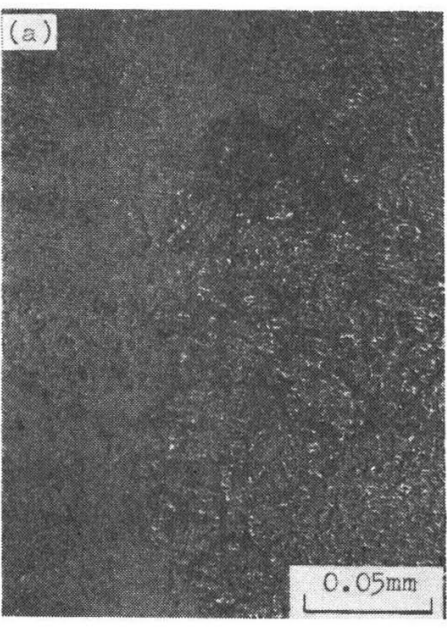

(a) Stator

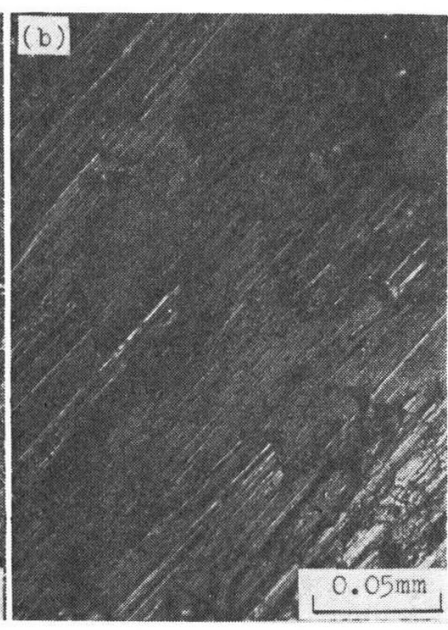

(b) Rotor
写真 1 リン酸塩皮膜処理した $\mathrm{S} 15 \mathrm{C}($ Rotor $)$ と焼入レ, 焼モドシ処理した $\mathrm{SKD} 11$ (Stator)を組只合わせ, 接触圧力 $500 \mathrm{~kg} / \mathrm{cm}^{2}$, スベリ速度 $0.20 \mathrm{~m} / \mathrm{s}$ のもとで, 距離 $100 \mathrm{~m}$ で摩耗を行なったときのスベリ面

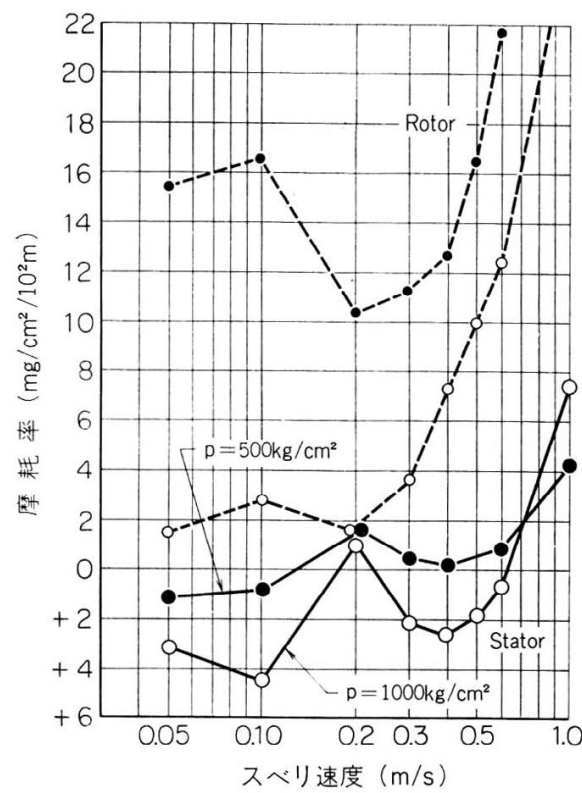

(試験片; Stator, SKD11 ( $980^{\circ} \mathrm{C}$, OilQ, $180^{\circ} \mathrm{C}$, Temper)

図 3 リン酸塩皮膜処理したS $15 \mathrm{C}$ と組っ合わせた SKD 11 の速度一摩耗特性曲線

図 3 は上述の実験結果を示したもので，これによると 接触圧力あるいはスベリ速度のいかんにかかわらず，初 期摩耗の段階で回転試験片のスペリ面に存在するリン酸 塩皮膜は容易に除去され，全般的に激しい摩耗現象を呈 することが認められた。

たと爷ば固定試験片に用いた SKD11 の摩耗現象につ いてみ、た場合，接触圧力 $500 \mathrm{~kg} / \mathrm{cm}^{2}$ ，スベリ速度 $0.20 \mathrm{~m}$ /s に拈いて実験開始直後からスベリ面には写真 1 a に みられるごとき凝着などに起因する激しい金属転移現象 が観察され，さらにスペリ距離が増すに ともなってヒッカキ状摩耗コンが多く現 われ摩耗率は最大值を表わすことが認め られた。またより低速側の速度 $0.10 \mathrm{~m} / \mathrm{s}$ 以下でもリン酸塩皮膜が除去された後の 回転試験片からの金属転移が激しく起こ り, 摩耗後試験片の重量はスベリ距離に 比例して増加の傾向を示す。しかるに高 速側の領域ではスベリ速度 $0.40 \mathrm{~m} / \mathrm{s}$ 付近 で摩耗率のいったん減少する傾向がみら れるが，速度 $0.60 \mathrm{~m} / \mathrm{s}$ 以上では摩擦熱の 影響を受けやすくなり，これによる激し い凝着とヒッカキ現象のため摩耗率はふ たたび増加がみられるようになる。

これに対して, 上述の固定試験片と組 み合わせた回転試験片の摩耗接触性は, 傾向的には固定試験片のそれと類似して いるが，さきにも述べたごとく初期摩耗 の段階で容易にリン酸塩皮膜が除去され 


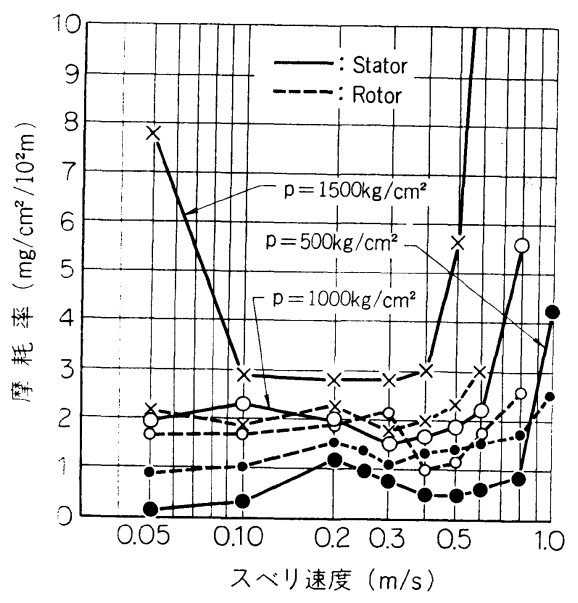

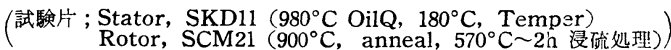

図 4 漫硫処理したSCM21 と組み合わせた SKD11 の速度一摩耗特性曲線

る関係上凝着が起こりやすく，乙かも固定試験片に比較 して機械的性質が低位であることから凝着コンやスベリ 面間に介在する摩耗粉末により写真 $1 \mathrm{~b}$ によらるごと きヒッカキ, 堀起こし現象が激しく起こり，これにとも なって顕著な摩耗損失が認められる。

つぎに接触圧力を $1000 \mathrm{~kg} / \mathrm{cm}^{2}$ として同様な実験を行 ない, その結果を図 3 に併記した。これによると, 両試 験片とも速度一摩耗特性曲線は上述の圧力 $500 \mathrm{~kg} / \mathrm{cm}^{2}$ の ときと類似した傾向がみられる。しかし，回転試験片の S15Cから固定試験片の SKD 11への金属転移，あるい はこれがさらに回転試験片へ再転移する現象がいっそら 顕著に現われ，このため固定試験片の摩耗損失は多くの 条件下で重量増加を起こし，回転試験片のそれは前述の 圧力 $500 \mathrm{~kg} / \mathrm{cm}^{2}$ のときよりも軽減される傾向にあること を認めた。

他方，上述の各実験に拈いて採取した摩耗粉末をX 線 回折により検討し，摩耗機構の解明を行なった。これに よると接触圧力ならびにスベリ速度のいかんにかかわら ず $\alpha-\mathrm{Fe}$ のみが同定され，これからも摩耗がリン酸塩皮 膜の除去された後の鋼同志の接触にともなって生ずる凝 着によって生じていることは明らかである。

以上の結果から，S15Cの回転試験片のスベリ面に施 したリン酸皮膜は摩耗の初期段階で容易に除去され，鋼 同志が直接接触を起こすことが原因となって激しい摩耗 を生ずるものと判断される。したがって冷間成形時に金 型と被加工材との間にかかる現象が生ずるときは, 被加 工材によって被加工材を成形することとなり，ますます 金属転移が起こりやすく，その結果として被加工品の精 度ならびに金型の寿命を著しく阻害するものと考えられ る。

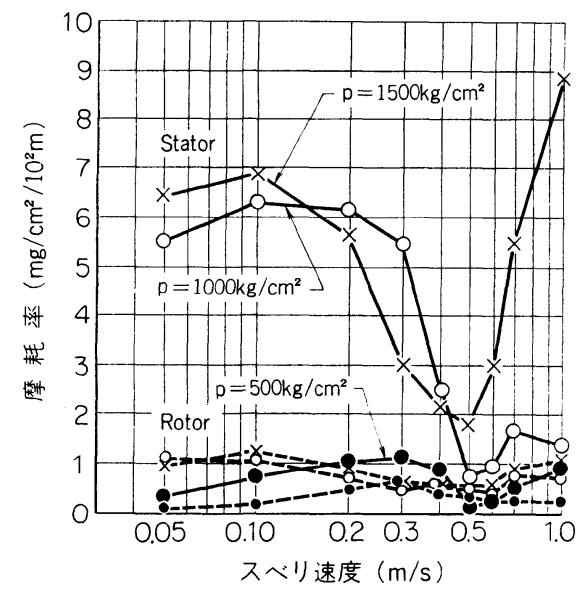

(試験片 ; Stator, SKH $9\left(1200^{\circ} \mathrm{C}\right.$. Oil? $560^{\circ} \mathrm{C}, 3$ 回, Temper)

図 5 浸硫処理した S 15C と組み合わせた SKH 9 の速 度一摩耗特性曲線

\section{4. 浸硫処理した鋼と組み合わせた高合金鋼 の摩耗特性}

回転試験片に $570^{\circ} \mathrm{C} \sim 2 \mathrm{~h}$ 浸硫処理した SCM 21 括よ びS 15Cを用い, これらを通常の条件で焼入レ, 焼モド シ処理したSKD11またはSKH 9 の固定試験片と組又合 わせて, 高負荷, 低速条件のもとで乾燥一スベリ摩耗を 行ない, その結果から速度一摩耗特性曲線を求めた。

図 4 はSKD11 とSCM21を組又合わせて接触圧力500, 1000 および $1500 \mathrm{~kg} / \mathrm{cm}^{2}$ のもとで, それぞれスべリ速度 を0.05〜 1.00m/s に変化させたときの速度一摩耗特性曲 線を示したすのである。

これによると, 固定摩験片の摩耗率が最大となる摩耗 条件は，接触圧力 $500 \mathrm{~kg} / \mathrm{cm}^{2}$ の場合 ス ベリ速度 0.20 $\mathrm{m} / \mathrm{s}$, 圧力 $1000 \mathrm{~kg} / \mathrm{cm}^{2}$ では速度 $0.10 \mathrm{~m} / \mathrm{s}, 1500 \mathrm{~kg} / \mathrm{cm}^{2}$ に拈いて0.05m/sまたはそれ以下となり，接触圧力が高 くなるほど低速側へ移行する傾向にある。したがって」: 述の諸条件よりも低速あるいは高速領域に㧍いて摩耗率 の減少がみられる。しかし圧力 $500 \mathrm{~kg} / \mathrm{cm}^{2}$ の場合, 速度 $0.80 \mathrm{~m} / \mathrm{s}, 1000 \mathrm{~kg} / \mathrm{cm}^{2}$ では $0.60 \mathrm{~m} / \mathrm{s}, 1500 \mathrm{~kg} / \mathrm{cm}^{2}$ にお いて0. $40 \mathrm{~m} / \mathrm{s}$ 付近から高速側でふたたび摩耗率の増加傾 向が認められた。しかしながらいずれの場合も回転試験 片のスベリ面には浸硫層が存在するため, リン酸塩皮膜 処理したときのよらな著しい凝着現象とこれにともなら 金属転移がみられず，摩耗後重量増加を表わすことはな い。また他方に沶いて浸硫層は多孔質であることか $ら^{5)}$, 後述のごとく摩耗の過程で摩耗粉末として脱落し やすく，その一部が固定試験片のスベリ面に付着して摩 耗は硫化物同志の接触状態のすとで起こるようになり, これに起因して摩擦抵抗が低下する ${ }^{6)}$ 関係上比較的低い 摩耗率を表わすものと推考される。

このような現象は回転試験片の摩耗においても表わ れ, 摩耗特性曲線は傾向的に固定試験片のそれと類似し 
ているが，激しい凝着が起こらないためリン酸塩皮膜処 理したものに比べて著しく摩耗損失が少ない。

つぎに浸硫処理したS $15 \mathrm{C}$ と普通焼入レ，焼モドシの SKH 9 を組み合わせて, 上述と同様な条件のもとで摩 耗実験を行なった。図5はその結果を示したものであ る。

すなわち接触圧力 $500 \mathrm{~kg} / \mathrm{cm}^{2}$ の場合は固定および回転 試験片ともスペリ速度 $0.30 \mathrm{~m} / \mathrm{s}$ において最大摩耗率を現 わすが，本実験の範囲では全般的に速度の増加にともな ら摩耗率の変化の少ないことが特徽である。しかるに接 触圧力が 1000 または $1500 \mathrm{~kg} / \mathrm{cm}^{2}$ のときはともにスベリ 速度0. $10 \mathrm{~m} / \mathrm{s}$ に打いて明らかに摩耗率は最大となり, 速 度 $0.50 \mathrm{~m} / \mathrm{s}$ の前後で一旦減少を示した後, より高速側で ふたたび摩耗損失の急激な増加が現われるよらになる。

換言すると, 各接触圧力のもとに护る速度一摩耗特 性曲線はいずれも傾向的に類似したものが得られる。し かし摩耗率については圧力 $500 \mathrm{~kg} / \mathrm{cm}^{2}$ と $1000 \mathrm{~kg} / \mathrm{cm}^{2}$ 以 上との間に顛著な差異のあることが認められた。

そこでこれらの摩耗機構を解明するため，スベリ面な らびに摩耗粉末の解析を行なった。まずスベリ面につい ては接触圧力 $1000 \mathrm{~kg} / \mathrm{cm}^{2}$ に打ける速度一摩耗特性曲線に 例をとり，摩耗率が著しく異なるときのスベリ速度

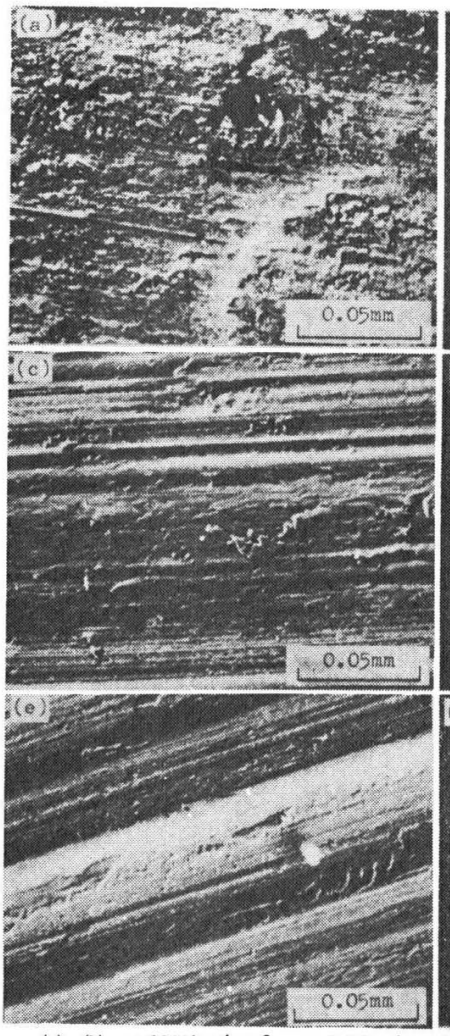

(a), (b) p $1000 \mathrm{~kg} / \mathrm{cm}^{2}, \quad \mathrm{v} 0.10 \mathrm{~m} / \mathrm{s}, \quad l 1000 \mathrm{~m}, 2$ 次電子線像打よび $\mathrm{SK} \alpha$ 線像 (c), (d) $\mathrm{p} 1000 \mathrm{~kg} / \mathrm{cm}^{2}, \quad$ v $0.50 \mathrm{~m} / \mathrm{s}, \quad l 1000 \mathrm{~m}$, (e), (f) $\mathrm{p} 1000 \mathrm{~kg} / \mathrm{cm}^{2}, \quad$ v $1.00 \mathrm{~m} / \mathrm{s}, \quad l 1000 \mathrm{~m}$,

写真 2 焼入レ, 焼モドシ処理した固定試験片（SKH９）の スベリ面とイオウの観察 $0.05 m$
$0.10,0.50$ 抌よび $1.00 \mathrm{~m} / \mathrm{s}$ のもとで摩耗を行なったとき の固定試験片のスペリ面をX.M. Aにより吟味した。写 真 $2 \mathrm{a} \sim 2 \mathrm{f}$ はその結果を示したもので, 2 次電子線像 ならびに $\mathrm{S} \cdot \mathrm{K} \alpha$ 線像から観察し得たスベリ面の状態は, 摩耗率が最大となる条件のもとで摩耗粉末となった回転 試験片のスペリ面に存在する浸硫層の一部が固定試験片 のそれに付着しているのを認めた。しかしより高速側で はヒッカキ状の摩耗コンが多くみられるよらになるにも かかわらず，スペリ面全体にわたってイオウ化合物を確 認することができた。

他方上述の諸条件で摩耗を行なったときに採取した摩 耗粉末についてX線回折によりその構成要素を検討し た。図 6はその一例として相対的に摩耗率の低い接触圧 力 $500 \mathrm{~kg} / \mathrm{cm}^{2}$ のもとで摩耗率が最大值を表わすスべリ速 度 $0.30 \mathrm{~m} / \mathrm{s}$, 最大摩耗率が明りょらに認められる圧力 $1500 \mathrm{~kg} / \mathrm{cm}^{2}$, 速度 $0.10 \mathrm{~m} / \mathrm{s}$ および高速側で摩耗率がい ったん減少したのちらたたび増加の傾向を呈する圧力 $1000 \mathrm{~kg} / \mathrm{cm}^{2}$, 速度 $1.00 \mathrm{~m} / \mathrm{s}$ の 3 条件で得られた摩耗粉 末のX線回折結果を示したものである。

これによると，いずれの場合も回転試験片のスベリ面 を構成する浸硫物質がそのほとんどを占め， ほかに $\alpha$ ・ $\mathrm{Fe}_{2} \mathrm{O}_{3}, \mathrm{Fe}_{3} \mathrm{O}_{4}$ などの酸化鉄を同定することができた。 またこのほかに 摩耗率が多いものほど $\alpha-\mathrm{Fe}$ の存在が明りょうに認められるよらになる。 このような結果から，本実験の範囲内に拉 いては摩耗条件のいかんにかかわらず摩耗機 構に本質的変化がみられず，固定試験片のス ペリ面に存在する多孔質な浸硫層が摩耗の過 程で脱落し，その一部が固定試験片のスペリ 面に付着して硫化物同志の摩擦，摩耗状態を 呈するものと判断された。

\section{(d) \\ 5. Under hardening を施した高 合金鋼の摩耗特性}

冷間成形加工などの金型にみられる衝撃破 壞を防ぐ目的で行なら熱処理法の一つである Under hardening を本実験の 固定試験片で ある SKD11拈よび SKH 9 に応用し，これら を浸硫処理したS15C と組及合わせて乾燥一

スペリ摩耗を行なった。

すなわら摩耗条件には前項と同様, 接触圧 力を 500,1000 抌よび $1500 \mathrm{~kg} / \mathrm{cm}^{2}$ の 3 種類と し，スベリ速度を0. 05〜 $1.00 \mathrm{~m} / \mathrm{s}$ の範囲に変 化させて各圧力のもとに护りる速度一摩耗特 性曲線を求めた。

図 7はその結果を示したもので，図中(a)は SKD11を固定試験片とした場合，また(b)は SKH 9 を固定試験片としたときの摩耗特性 曲線である。これらを比較すると，いずれも きわめて類似した摩耗率の増減傾向を現わす ことが認められる。すなわち上述の圧力範囲 
ではスベリ速度 $0.10 \mathrm{~m} / \mathrm{s}$ 付近に打いて固定なら びに回転試験片とも摩耗率は最大となり，より 高速側でいったん減少したのちらたたび増加の 傾向がみられる。また固定試験片として用いた SKD11と SKH 9の最大摩耗率と比較すると, ややカタサにすぐれた SKH 9 のほうが SKD11 よりもわずかに低い值を示している。しかしな がらこれらの結果を前揭図 4 または図 5 の普通 焼入レ，焼モドシ処理したものと比べた場合い ずれも摩耗率が大きく，ことに上述と同様な摩 耗条件においてこの傾向が顕著に認められた。

そこでこの摩耗機構を解明するため, 前項で 述べたと同様な方法によりスベリ面ならびに摩 耗粉末の検討を行なった。写真 $3 \mathrm{a} \sim \mathrm{f}$ は一例 として接触圧力を $1000 \mathrm{~kg} / \mathrm{cm}^{2}$ とし, スベリ速 度0.10，0.50および $1.00 \mathrm{~m} / \mathrm{s}$ のもとで距離 1000 $\mathrm{m}$ 摩耗を行なったときの SKH 9 の固定試験片 に拈けるスベリ面の状態ならびに $\mathrm{S} \cdot \mathrm{K} \alpha$ を線像 を示したものである。これによるとスベリ面の 摩耗状態ならびにイオウ化合物の付着状況は前 掲写真 2 a〜 f ときわめて類似している。すな わちスベリ速度 $0.10 \mathrm{~m} / \mathrm{s}$ の摩耗率が最大となる 条件ではイオウ化合物を含む摩耗粉末の付着が 明りょらに観察され，速度 0.50 または $1.00 \mathrm{~m} / \mathrm{s}$ の比較的高速条件下ではヒッカキ状摩耗コンが 多いにもかかわらずイオウ 化合物の付着を認めること ができた。

またそれぞれの摩耗実験 で採取された摩耗粉末をX 線回折した結果からは, い ずれの場合も図 6 と同様 $\mathrm{FeS}, \mathrm{Fe}_{3} \mathrm{~N}$ などの浸硫層を 構成する要素と $\alpha \cdot \mathrm{Fe}_{2} \mathrm{O}_{3}$, $\mathrm{Fe}_{3} \mathrm{O}_{4}$ などの酸化物が $\alpha$. $\mathrm{Fe}$ と混在して同定された。

したがって機構的観点か らは普通焼入レ, 焼モドシ を施した高合金鋼も， Under hardening を行な ったものも類似していると みることができる。

\section{6. 結言}

本研究は冷間成形加工な どの金型材料としてはん用 されている高炭素高クロム
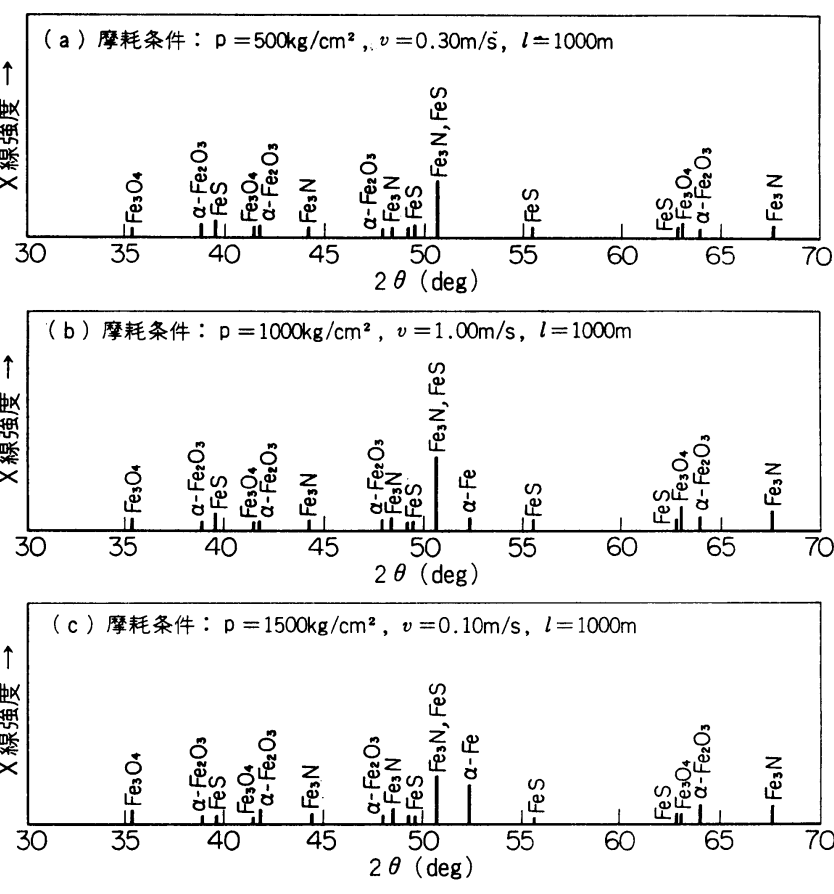

試䀫片; Stator, SKH $9\left(1200^{\circ} \mathrm{C}, \mathrm{OilQ}, 560^{\circ} \mathrm{C}, 3\right.$ 回, Temper) Rotor, S15C $\left(900^{\circ} \mathrm{C}\right.$, anneal, $570^{\circ} \mathrm{C} \sim 2 \mathrm{~h}$, 漫硫処理)

X線回折条件; Target, Co, Filter, Fe, Valtage, $30 \mathrm{kVp}$, Current, $10 \mathrm{~mA}$

図 6 採取した摩耗粉末のX線回折結果の一例
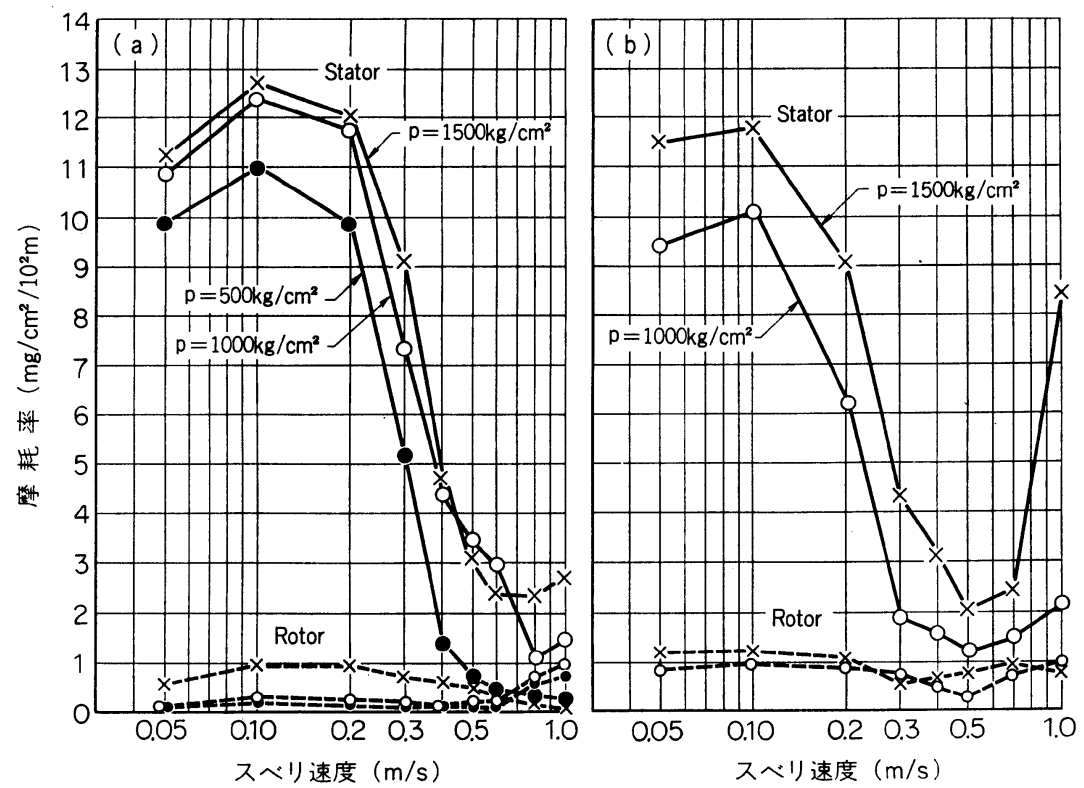

試験片 ; Stator (a) SKD11 $\left(880^{\circ} \mathrm{C}\right.$, OilQ, $180^{\circ} \mathrm{C}$, Temper)

(b) $\mathrm{SKH} 9\left(1050^{\circ} \mathrm{C}\right.$, OilQ, $250^{\circ} \mathrm{C}$, Temper $)$

Rotor (a) (b) 共通 $\mathrm{S} 15 \mathrm{C}\left(900^{\circ} \mathrm{C}\right.$, anneal, $570^{\circ} \mathrm{C} \sim 2 \mathrm{~h}$, 浸硫処理)

图 7 漫硫処理した S 15C と組み合わせた高合金鋼（Under hardening） の速度一摩耗特性曲線 
ダイス鋼（SKD 11）ならびにモリブデン系高速度鋼 （SKH 9）とリン酸塩皮膜をたは浸硫処理した低炭素構 造用鋼（S15C， SCM 21）を組み合わせ，接触圧力500 $\sim 1500 \mathrm{~kg} / \mathrm{cm}^{2}$, スベリ速度0.05 1. $00 \mathrm{~m} / \mathrm{s}$ の高圧一低速 条件下に和ける乾燥ースベリ摩耗特性について検討した ものである。つぎにその結果を要約すると，

i）焼入レ，焼モドシ処理を施したSKD11の固定試 験片とリン酸塩皮膜処理した S $15 \mathrm{C}$ の回転試験片を組み 合わせた場合，摩耗条件のいかんにかかわらず初期摩耗 の段階で容易にリン酸塩皮膜がハク離し，鋼同志の摩耗 となるため激しい凝着が起こり，これにともなら金属転 移現象が固定試験片のスベリ面に観察された。

ii）焼入レ，焼モドシを施したSKD11またはSKH 9 之浸硫処理した低炭素鋼を組み合わせた場合, 各試験片 ともスベリ速度 $0.10 \mathrm{~m} / \mathrm{s}$ 前後の比較的低速領域において 摩耗率は最大值を示し, 漸次速度が増すにともなって減 少するがより高速側ではふたたび増加の現象がみられ る。また最大摩耗率は接触圧力が高くなるほど低速側へ 移行する傾向がある。
iii）耐衝撃性を向上させる目的からSKD11および SKH 9 亿 Under hardening を施し，これと浸硫処理し たS 15Cを組み合わせたときの摩耗特性は前項のそれと 医㴽類似した結果が得られた。しかしややカタサが低い ため普通焼入レ，焼モドシのものに比べて摩耗率はわず かに大きくなることを認めた。

iv）浸硫処理した 鋼を組み合わせた 高合金錀の速度一 摩耗特性曲線には接触圧力のいかんにかかわらず，スべ リ速度の增加にともなって摩耗率の增減傾向が双られる が，スベリ面あるいは摩耗粉末を観察した結果からは機 構的に顕著な差異が認められなかった。すなわちいずれ の場合も高負荷条件のもとで多孔質な浸硫層が摩耗粉末 として脱落し，その一部が相手側スベリ面に付着して凝 着を起こしにくい7)スベリ面同志の摩耗となるため摩耗 率の減少がみられるよらになる。

な怙本研究は昭和 45 年度中小企業庁技術開発研究補助 金を受けて行なったものであり，研究の遂行に当たって は終始実験に協力してくださった芝浦工業大学学生安藤 直茂君に深く感謝の意を表します。

\section{（1972-10-27 受理） \\ 文献}
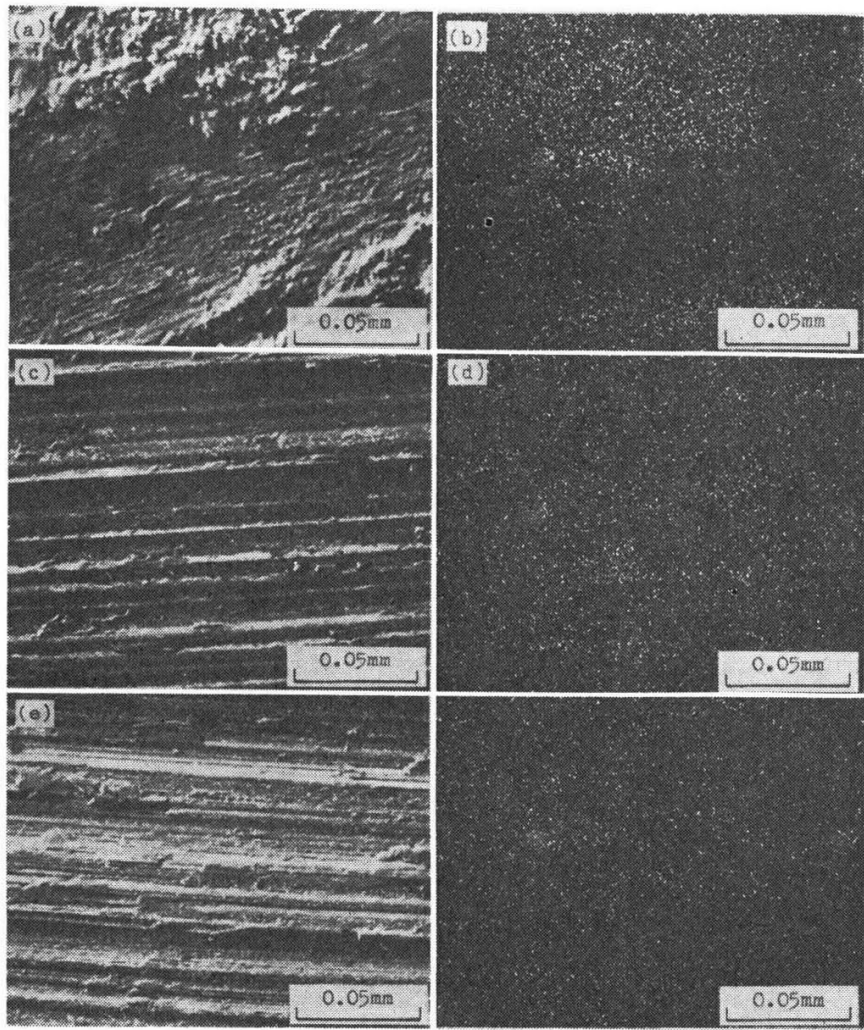

1）たと壳ば"，裏川，R\&D，19，No. 2 147 (1969)

2) A. Kannappan, Netal Forming, 37, 6 (1970)

3) 竹内, 日本金属学会誌, 35, 671(1971)

4) 竹内, 鋳鉄の摩耗, P.20（1968, 誠 交堂新光社版)

5) R. B. Waterhouse, Wear, 8, 421 (1966)

6) F. P. Bowden and D. Tabor, The Friction and Lubrication of Solids (I) P. 237 (1950 Oxford Press)

7) 竹内, 3) と同し

(a), (b) $\mathrm{p} 1000 \mathrm{~kg} / \mathrm{cm}^{2}, v 0.10 \mathrm{~m} / \mathrm{s}, l 1000 \mathrm{~m} 2$ 次電子線像扰よび $\mathrm{SK} \alpha$ 線像 (c), (d) $\mathrm{p} 1000 \mathrm{~kg} / \mathrm{cm}^{2}$, v $0.50 \mathrm{~m} / \mathrm{s}, l 1000 \mathrm{~m}$ (e), (f) $\mathrm{p} 1000 \mathrm{~kg} / \mathrm{cm}^{2}$, v $1.00 \mathrm{~m} / \mathrm{s}, l 1000 \mathrm{~m}$

写真 3 Under hardening した固定試験片（SKH 9）の スベリ面とイオウの観察 